\title{
KATALÓG CESTOVNEJ KANCELÁRIE - JEHO TVORBA A DISTRIBÚCIA
}

\section{Kristína Pompurová}

\section{Kl’účové slová:}

cestovná kancelária, distribúcia, katalóg, tvorba katalógu

\section{Key words:}

brochure, distribution, brochure production, tour operator

\begin{abstract}
Abstrakt
Katalóg je základný komunikačný, prezentačný a propagačný nástroj cestovnej kancelárie. Aby mohol vo vzt'ahu k zákazníkom plnit' svoje funkcie, dôležité je venovat' primeranú pozornost' jeho tvorbe (kreatívnemu návrhu, tlači) a distribúcii. Ide o náročný proces (organizačne, finančne), ktorý pozostáva z viacerých fáz a často sa na ňom podiel'ajú aj externé inštitúcie. Ciel'om state je preskúmat' tvorbu a distribúciu katalógov vo vybraných slovenských cestovných kanceláriách a konfrontovat' ju s vymedzenou teóriou.
\end{abstract}

\begin{abstract}
The Brochure is a basic communication, presentation and promotional tour operator's tool. In order to fulfill its functions, tour operators have to pay an adequate attention to it production (creative design, printing) and distribution. This is a difficult process (organizationally, financially), which consists of several stages and often involving external organizations. The aim of the article is also to examine the production and distribution of brochures in selected Slovak tour operators and confront it with the theory.
\end{abstract}

\section{Úvod}

Katalóg je základným nástrojom predaja cestovnej kancelárie. Ide o tlačený alebo elektronický materiál, ktorý primárne slúži ako zdroj informácií pre existujúcich a potenciálnych zákazníkov organizácie, ale využíva sa aj pre potreby distribučnej siete. Obsahuje zrozumitel'né, viac alebo menej podrobné informácie o ponúkaných produktoch cestovnej kancelárie na určité obdobie, ciel'ových miestach a zariadeniach, v ktorých sa produkty poskytujú vrátane cien produktov, fotografií a d'alších ilustrácií. Jeho ciel'om je vytvorit' povedomie o ponuke organizácie, stimulovat' dopyt po vybraných produktoch, ul'ahčit' kúpu a optimalizovat' spotrebu produktov. Prostredníctvom katalógu si cestovné kancelárie budujú svoj imidž, determinujú umiestnenie svojich produktov na trhu a poskytujú informácie, ktoré majú uistit' zákazníkov i sprostredkovatel'ov o dôveryhodnosti a stabilnom postavení organizácie. V závislosti od rozsahu ponuky sa rozhodujú medzi rozsiahlejšími všeobecnými katalógmi a špecializovanými katalógmi, ktoré môžu byt' určené pre istý segment (mladých, rodiny s det'mi, náročnejších zákazníkov, inštitucionálnych zákazníkov, školské kolektívy ap.), zamerané na vybraný druh cestovného ruchu (domáce, zahraničné zájazdy a pobyty), určitý typ produktu (kúpel'né pobyty, lyžovačky, dovolenky pri mori, exotické zájazdy, poznávacie zájazdy ap.), prípadne konkrétne ciel’ové miesto (Egypt, Tunisko, Turecko ap.). Svoj účel môže katalóg plnit' nielen v mieste predaja produktov cestovnej kancelárie a na webovej stránke organizácie, ale aj v miestach, kde sa zdržiavajú potenciálni zákazníci ( $\mathrm{v}$ mieste bydliska, na pracovisku, v obchodných centrách ap.). Jeho tvorba a distribúcia sa hradí z marketingového rozpočtu cestovnej kancelárie. 
Napriek tomu, že sa čoraz viac do popredia dostáva virtuálny - elektronický katalóg (úspora materiálu, flexibilnost', väčšia prehl'adnost', ul'ahčenie výberu produktov podl'a vybraných kritérií, možnost' poskytnút' väčší rozsah informácií, fotografií, odporúčaní, doplnit' informácie o videá, skúsenosti zákazníkov ap.), cestovné kancelárie venujú stále značné úsilie, čas, energiu a prostriedky na tvorbu a distribúciu tlačeného katalógu.

\section{Teoretické východiská skúmanej problematiky}

\subsection{Funkcie, štruktúra a obsah tlačeného katalógu}

Tlačený katalóg je viazaný dokument vo forme brožúry. Obyčajne má kvôli stojanom, v ktorých sa ponúka, štandardizovaný formát A4. Slúži ako základný komunikačný, prezentačný a propagačný nástroj, prostredníctvom ktorého cestovná kancelária komunikuje so svojimi zákazníkmi. Ako uvádza Horner a Swarbocke (2004), v cestovných kanceláriách zohráva ovel'a dôležitejšiu úlohu ako v iných organizáciách cestovného ruchu. Podl'a Middletona (1995, s. 192):

- šetrí čas, resp. znižuje dížku kontaktu predajcu so zákazníkom, ktorý pred uskutočnením kúpy potrebuje podrobné informácie o luxusnom statku (produkty cestovného ruchu nie sú predmetom každodennej spotreby),

- zabezpečuje trvalú komunikáciu so zákazníkom (pred, počas a po kúpe),

- je hmatatel’ným zdrojom očakávaní zákazníka (v dôsledku toho, že zákazník si produkt cestovnej kancelárie nemôže vopred vyskúšat', predaj produktu a jeho spotreba sú časovo a priestorovo oddelené),

- optimalizuje zážitok zo spotreby (je zdrojom užitočných informácií),

- zabezpečuje dodatočné výdavky zákazníka (obsahuje informácie o d'alších komplementárnych produktoch, napr. fakultatívnych výletoch).

Middleton (1995, s. 192 - 194) d'alej spomína viacero funkcií, ktoré tlačený katalóg plní vo vzt’ahu k zákazníkom cestovnej kancelárie. Ide najmä o:

- funkciu vytvorenia povedomia o cestovnej kancelárii. Katalóg má prostredníctvom svojho obalu vzbudit' pozornost' potenciálnych zákazníkov. Obal katalógu sa pritom prirovnáva k obalu tovarov. Jeho úlohou je zaujat', informovat' o organizácii a vytvorit' k nej preferenciu;

- propagačnú funkciu. Katalóg má úlohu živého výkladu. Má stimulovat' zákazníkov, motivovat' ich ku kúpe. Je nositel'om kl'účovej správy, ktorú chce organizácia šírit' svojmu okoliu (obchodným partnerom, zákazníkom, širšej verejnosti). Prostredníctvom fotografií identifikuje potreby potenciálnych zákazníkov, umiestňuje organizáciu a jej produkty na trhu, vytvára imidž organizácie;

substitučnú funkciu. Katalóg predstavuje v čase kúpy pre zákazníka (najmä takého, ktorý ešte nemá vlastnú skúsenost') produkt. Vytvára očakávania o kvalite, hodnote za peniaze, imidž produktu a jeho status, ktorý nemusí byt' zhodný so spotrebovaným produktom;

- funkciu sprostredkovania kúpy produktu. Katalóg zvyčajne obsahuje kontakty na autorizovaných predajcov produktu (zoznam predajných miest), ako aj možnosti rezervovania (zoznam webových stránok, e-mailových adries, telefónnych čísel), ktoré zákazníkovi ul'ahčujú prístup k produktu cestovnej kancelárie;

- funkciu uistenia zákazníka o kúpe. V období medzi kúpou a spotrebou produktu (ktoré môže trvat' aj niekol'ko mesiacov) slúži katalóg ako dôkaz kúpy. Zákazníci ho v tomto období čítajú ako hmotnú pripomienku kúpeného produktu a ukazujú ho priatel'om a známym. Zákazníkom nespokojným so skutočným produktom dáva obsah katalógu právo st’ažovat' sa a dožadovat' kompenzácie; 
- funkciu ul'ahčenia spotreby. Katalóg obsahuje základné informácie, ktoré majú zákazníkom ul'ahčit' cestu a pobyt, prípadne zvýšit' hodnotu kúpeného produktu;

- funkciu vzdelávania. Katalóg má na zákazníkov pôsobit' a vytvárat' v nich povedomie o potrebe trvaloudržatel'ného rozvoja ciel'ových miest, tvorbe a zachovaní atraktívneho a zdravého životného prostredia.

Za určujúcu pritom z hl'adiska zákazníka považujeme propagačnú, substitučnú funkciu, ako aj funkciu ul'ahčenia spotreby.

Katalóg je možné vnútorne rozdelit' na niekol'ko častí. Holloway (2004, s. 289 - 290) rozlišuje obal, vstupnú čast', vlastnú ponuku produktov a záverečnú čast'. Obal je pritom podl'a neho kl'účom k presviedčaniu zákazníkov, aby zvážili kúpu vybraného produktu. Obsahuje názov cestovnej kancelárie, jej logo, označenie platnosti katalógu, naznačenie jeho obsahu a obrázok, ktorý zachytáva určité ciel'ové miesto (alebo jeho významnú atraktivitu), prípadne dovolenkovú atmosféru (napr. št’astná rodina, ktorá šantí pri bazéne, na pláži, svahu ap.). Niektoré cestovné kancelárie robia len minimálne modifikácie obalu katalógu, snažia sa o to, aby bol pre zákazníkov, ale aj predajcov l'ahšie identifikovatel'ný. Ked’že sa cestovné kancelárie boja riskovat', obaly katalógov bývajú jednotvárne, bez predstavivosti. Líšia sa len orientáciou strán (na výšku, na šírku).

Obsah a usporiadanie vstupných častí katalógu bývajú diferencované. Úvodné strany predznamenávajú charakter ponuky a obchodnú politiku, uist'ujú o dôveryhodnosti cestovnej kancelárie a propagujú jej USP (unique selling proposition) - jedinečné predpoklady predaja, ktoré súvisia s ponúkaným produktom. Môžu zahŕňat' príhovor (oslovenie potenciálnych zákazníkov, vytvorenie preferencie pre kúpu, vysvetlenie poslania a významu katalógu), obsah, resp. pokyny pre l'ahšiu orientáciu v katalógu, pokyny pre manipuláciu s katalógom (vysvetlenie významu piktogramov a vybraných pojmov), všeobecné informácie (informácie o možnostiach získania zl'avy, o spôsobe platby, kontakty ap.).

Vlastná ponuka produktov je zvyčajne usporiadaná podl'a ciel'ových miest (krajín, regiónov, stredísk) do niekol'kých samostatných sekcií. Ponuka pritom začína bud' ciel'ovými miestami, ktoré cestovná kancelária uvádza na trh ako novinku, alebo ciel'ovými miestami, o ktoré je najväčší záujem (ktoré tvoria podstatnú čast' produktu cestovnej kancelárie). Jednotlivé sekcie obsahujú všeobecné informácie o ciel'ovom mieste (vrátane jednoduchej orientačnej mapy s vyznačením umiestnenia ubytovacích zariadení), konkrétnu ponuku zájazdov, v ktorej sa kladie dôraz najmä na ubytovacie zariadenia (dôležité sú fotografie interiéru a exteriéru zariadení - bazénov) a cenník s detailmi o jednotlivých termínoch zájazdov a pobytov, dížke ich trvania, nástupných miestach ap. Niektoré cestovné kancelárie vylučujú cenníky z ponuky zájazdov a presúvajú ich do záverečnej časti katalógu, prípadne ich uverejňujú osobitne. Dôvodom je, že v čase tvorby katalógu nemajú vykalkulované ceny zájazdov (nepoznajú presné ceny nakupovaných služieb), resp. sa snažia ušetrit' náklady na tlač (cenníky sa zvyčajne tlačia na menej kvalitnom papieri). Zákazníkom to môže zhoršit' prehl'adnost', orientáciu a porovnávanie ponúk.

Záverečná čast' katalógu obsahuje všeobecné zmluvné podmienky cestovnej kancelárie (niekedy aj reklamačný poriadok), adresy a kontakty predajných miest, možnosti rezervovania produktov, prípadne informácie o obchodných partneroch. Niektoré cestovné kancelárie dávajú v záverečnej časti aj priestor na reklamu tovarov a služieb súvisiacich s cestovaním (napr. reklama komerčnej poist’ovne, reklama na opal'ovacie krémy, slnečné okuliare, cestovatel'skú literatúru), z ktorej čiastočne financujú tvorbu a tlač katalógu. 
Obsah katalógu je pre organizátorov zájazdov, ako i pre predajcov záväzný, je súčast'ou zmluvy o obstaraní zájazdu. Nespokojným zákazníkom dáva právo st’ažovat' sa a dožadovat' kompenzácie. Podlieha prísnej európskej legislatíve (Smernica Rady Európy o balíku cestovných, dovolenkových a výletných služieb 90/314/EEC), ktorá určuje minimálny rozsah informácií uvedených v katalógu. Na Slovensku bola smernica zavedená do legislatívy v roku 2001 ako Zákon o zájazdoch, podl’a ktorého je cestovná kancelária povinná v katalógu presne, jasne, pravdivo, zrozumitel'ne, úplne a riadne informovat' o všetkých skutočnostiach, ktoré sú jej známe, a ktoré môžu mat' vplyv na rozhodnutie záujemcu o kúpu zájazdu, najmä však o:

- termíne začatia a skončenia zájazdu,

- cene zájazdu vrátane časového rozvrhu platieb a výške preddavku, prípadoch, ked' je objednávatel' povinný zaplatit' cestovnej kancelárii zmluvnú pokutu pri odstúpení od zmluvy o zájazde, a o výške tejto zmluvnej pokuty ustanovenej v závislosti od času odstúpenia,

- ciel'ovom mieste a mieste pobytu,

- druhu dopravného prostriedku, úrovni jeho vybavenosti, kvality a triedy,

- type ubytovania, jeho polohe, kategórii, stupni vybavenosti a o hlavných charakteristických znakoch,

- rozsahu stravovania a o jeho forme,

- trase cesty, predpokladaných časoch a o miestach zastávok,

- všeobecných údajoch týkajúcich sa pasových a vízových požiadaviek pre občanov Slovenskej republiky a o zdravotných formalitách, ktoré sú nevyhnutné na cestu a pobyt, ako aj o zvyčajných cenách a lehotách na ich vybavenie,

- tom, či sa pre zájazd požaduje minimálny počet účastníkov zájazdu vrátane termínu, kedy najneskôr pred odchodom sa musí objednávatel'ovi oznámit', že sa nedosiahol minimálny počet účastníkov zájazdu a cestovná kancelária zájazd zrušuje,

- rozsahu a podmienkach povinného zmluvného poistenia zájazdu, o rozsahu poistného plnenia, o podmienkach na plnenie nároku objednávatel'a, o poistitel'ovi, s ktorým má cestovná kancelária uzatvorené povinné zmluvné poistenie zájazdu,

- programe $\mathrm{v}$ mieste pobytu,

- lehote, v ktorej môže objednávatel' oznámit', že sa zájazdu namiesto neho zúčastní iná osoba, ak sú dôvody na jej určenie, a o podmienkach, ktoré musí účastník poskytovaného zájazdu spĺn̆at', ak sú dôvody na ich ustanovenie,

- možnosti uzatvorit' individuálne poistenie objednávatel'a na cestu a pobyt vrátane poistenia pre prípad, že objednávatel'ovi vzniknú náklady v súvislosti s jeho odstúpením od zmluvy o zájazde v prípade nehody alebo ochorenia,

- rozsahu a kvalite všetkých ostatných plnení, ktoré sú obsahom zájazdu.

Potenciálni zákazníci hodnotia tlačený katalóg cestovnej kancelárie na základe kombinácie niekol'kých faktorov. Posudzujú najmä prít'ažlivost' obalu, kvalitu a lesk papiera, použitie farieb a ich pôsobivost', počet a kvalitu fotografií ako i d'alších ilustrácií, rozsah, zrozumitel'nost' textu, význam a atraktívnost' ponúkaných produktov (Middleton, Fyall, Morgan, Ranchhod, 2009, s. 288 - 289). Podl'a Kumara (2005, s. 46) sa význam pripisuje predovšetkým kvalite papiera, grafickej úprave a rozmiestneniu textu a fotografií. Gúčik (2004, s. 117), naznačuje, že dôležitým kritériom je aj jednoduchost' práce s katalógom.

Ako uvádzajú Horner a Swarbocke (2004), niektoré praktiky môžu zákazníkov naopak odradit' od kúpy, resp. po konfrontácii katalógu so skutočnost’ou byt' zdrojom sklamania, ktoré môže vyústit' do st’ažností. Ide najmä o povrchné stereotypné opisy ciel'ových miest, nepriamo formulované negatívne charakteristiky ciel'ových miest a zariadení (napr. „rozrastajúce sa stredisko“ namiesto „, stredisku pokračujú práce na stavbe“), sporné 
odporúčania a označenia vhodnosti strediska alebo zariadenia pre určitú ciel'ovú skupinu (napr. zákazník sa spol'ahne na označenie „vhodné pre rodiny s det'mi“ a po zistení, že stredisko nie je pre neho vhodné sa cíti oklamaný), uvádzanie dôležitých informácií malými písmenami (v zákazníkoch to zanecháva pocit, že ich chce cestovná kancelária podviest'), kontroverzné uvádzanie cien zájazdov (ceny sú uvádzané bez povinných príplatkov, t. j. propagovaná cena je nižšia, než konečná suma, ktorú zákazník zaplatí za zájazd). Rozčarovanie vyvoláva aj rozdiel medzi fotkami v katalógu (napr. slnečná obloha, rušné ulice, otvorené terasy) a skutočnost'ou (napr. upršané počasie, zatvorené zariadenia). V katalógoch sa preto odporúča upozornit’ zákazníkov na rozdiely v jednotlivých ponúkaných termínoch (sezóna, mimosezóna).

Katalóg cestovnej kancelárie má vyvážit' potrebu zákazníkov po pravdivých, zrozumitel’ných a potrebných informáciách a snahu cestovnej kancelárie predat' produkt. Rozvíjajúca sa legislatíva a tlak zákazníkov by mali cestovné kancelárie podnietit', aby sa ešte dôslednejšie zamerali na detaily uvádzané v katalógoch a informovali napríklad aj o všetkých druhoch potenciálnych rizík spojených so spotrebou ponúkaných produktov.

\subsection{Tvorba a distribúcia katalógu}

Ako spomína Kumar (2005, s. 45), kým niektoré cestovné kancelárie si navrhujú katalógy sami, iné pri ich tvorbe spolupracujú s grafickým štúdiom vybranej reklamnej agentúry. Usporiadanie textu a obrázkov im pritom ul'ahčuje nakladatel'ský softvér (napr. Adobe InDesign). Bez ohl'adu na subjekt, ktorý koncipuje katalóg možno podl'a Middletona (1995, s. 195) hovorit' o šiestich fázach tvorby katalógu:

1. určenie rozsahu a formátu podl'a charakteru a potrieb ciel'ovej skupiny zákazníkov. Rozsah katalógov sa pritom podl'a Attla (2002, s. 47) pod vplyvom konkurencie, ako aj rastúcich požiadaviek zákazníkov i legislatívy na objem sprostredkúvaných informácií zvyšuje;

2. determinovanie vysielaného imidžu v závislosti od cielového segmentu - rozhodnutie o kvalite papiera, grafike, ústredných farbách, štýle písania, hutnosti textu, type písma, množstve fotografií ap. Pri produktoch určených náročnejším zákazníkom sa dôraz kladie na t’ažší papier, menej textu, pastelové farby a tematické fotografie, pri cenovo dostupnejších produktoch naopak na výrazné farby a viac textu. Fotografie v katalógoch pritom majú mat' vysoké rozlíšenie. Pokial' ide o známe atraktivity (napr. Eiffelova veža, Big Ben ap.), odporúča sa uverejňovat' fotky z netradičných uhlov, ktoré pôsobia osviežujúco;

3. špecifikovanie ciel’ov katalógu - spresnenie správy, ktorú chce cestovná kancelária vysielat' vybranej skupine zákazníkov;

4. rozhodnutie o distribúcii. Môže íst' o zasielanie katalógov zákazníkom, ktorí si v minulosti zakúpili produkty cestovnej kancelárie, zasielanie katalógov vybraným potenciálnym zákazníkom (najmä inštitucionálnym), distribúciu katalógov prostredníctvom výstav a vel'trhov cestovného ruchu, prostredníctvom siete províznych predajcov ap. V závislosti od zvolenej distribúcie je d'alej dôležité kvantifikovat', kol'ko katalógov bude cestovná kancelária potrebovat' Ako zdôrazňuje Holloway (2005, s. 291), cestovná kancelária by mala objednat' radšej viac výtlačkov a vyhnút' sa dodatočnej tlači, ktorá je finančne náročnejšia;

5. kreatívna realizácia. Kl’účový je predovšetkým výber obalu katalógu, kde sa zvažuje viac alternatív;

6. synchronizácia aktivit. Katalógy majú plnit' určitú úlohu v presne vymedzenom čase. Ich tvorba má byt' koordinovaná tak, aby boli k dispozícii $\mathrm{k}$ určitému termínu (napr. pred uskutočnením výstavy cestovného ruchu). Tvorba katalógu sa preto musí spustit' niekol'ko mesiacov pred želaným začatím predaja produktov (napr. katalógy na letnú sezónu sa začínajú tvorit’ na konci predchádzajúcej letnej sezóny). 
Ked’že náklady na distribúciu môžu niekedy presiahnut' náklady na tvorbu katalógu, dôležité je sledovat' výkonnost' províznych predajcov a počet katalógov distribuovaných sprostredkovatel'om prispôsobit' tomu, kol'ko produktov cestovnej kancelárie dokážu v priemere ročne predat'. Page (2009) hovorí že na európskom trhu sa až 80 \% zájazdov predáva prostredníctvom $20 \%$ predajcov. Odporúča sa preto, aby cestovné kancelárie roztriedili svojich predajcov do niekol'kých skupín, napr. výkonní predajcovia (ktorí predajú sto a viac zájazdov ročne), priemerní predajcovia (pät' až sto zájazdov ročne) a málo výkonní predajcovia (menej ako pät' zájazdov ročne), a prispôsobili im svoju distribučnú politiku. Vhodné je tiež sledovat', akým spôsobom predajcovia zaobchádzajú s katalógmi. Niektorí provízni predajcovia zákazníkom umožnia vol'ný prístup ku katalógom (katalógy umiestnia v stojanoch), iní naopak dajú k dispozícii len jeden katalóg, ktorý si zákazníci v prípade záujmu musia vyžiadat'.

V mnohých prípadoch je možné hovorit' o plytvaní spojenom s distribúciou tlačených katalógov. Podla štúdie realizovanej v Spojených štátoch amerických až $60 \%$ predajcov neotvorí všetky balíky s katalógmi cestovných kancelárií (Middleton, Fyall, Morgan, Ranchhod, 2009, s. 319). Page (2009, s. 323) uvádza, že na jeden predaný zájazd (pre tri osoby, prípadne väčšiu skupinu osôb) pripadá až 20 distribuovaných katalógov. Middleton, Morgan a Ranchhod (2009, s. 319) upresňujú, že v Spojenom král'ovstve je na získanie jedného zákazníka potrebných 4 až 15 katalógov, pritom v prípade menších cestovných kancelárii ide ešte o väčší počet.

Napriek rozvoju technológii tlače a uplatňovaniu outsourcingu, sú náklady na návrh, tlač a distribúciu katalógov stále vysoké. V závislosti od počtu strán sa pohybujú od jedného do šiestich eur za jeden katalóg, čo pri náklade niekol'ko tisíc kusov predstavuje značnú sumu. Cestovná kancelária First Choice v roku 2005 zverejnila informáciu, že tvorba a tlač katalógov ich ročne stojí 16 miliónov libier (ich hrubý zisk pred zdanením pritom predstavuje 115 miliónov) (Middleton, Fyall, Morgan, Ranchhod, 2009, s. 319).

\section{Ciel', materiál a metodika skúmania}

Ciel'om state je formou prípadových štúdií preskúmat' tvorbu a distribúciu katalógov vo vybraných slovenských cestovných kanceláriách a konfrontovat' ju s vymedzenou teóriou. Kvalitatívny prieskum uskutočníme prostredníctvom osobných rozhovorov so zamestnancami vybraných cestovných kancelárií. Vzhl'adom na vedomosti oslovených zamestnancov a ochotu cestovných kancelárií zverejňovat’ informácie sa rozsah poskytnutých údajov rôzni.

Subjektom skúmania je pät' slovenských cestovných kancelárií, ktoré sa líšia vel'kost'ou, územnou pôsobnost'ou i právnou formou. Na trhu organizovaného cestovného ruchu pôsobia viac ako desat' rokov. Označíme ich ako cestovné kancelárie A, B, C, D a E.

Cestovná kancelária A vznikla v roku 1999 rozšírením predmetu podnikania akciovej spoločnosti založenej v roku 1992. Sídli mimo hlavného mesta (na východnom Slovensku), má jednu prevádzkareň. Cestovná kancelária B vznikla v roku 1995. Je živnostenským podnikom, má jednu prevádzkareň mimo hlavného mesta (na strednom Slovensku). Cestovná kancelária C vznikla v roku 1992, podniká ako spoločnost' s ručením obmedzeným, sídli v hlavnom meste, má jedenást' prevádzkarni. Cestovná kancelária E bola vytvorená v roku 1992. Je živnostenským podnikom s jednou prevádzkarňou v hlavnom meste. Cestovná kancelária E vznikla v roku 1993 ako spoločnost' s ručením obmedzeným. Sídli mimo hlavného mesta (na západnom Slovensku) a má osem prevádzkarni. 


\section{Výsledky a diskusia}

\subsection{Tvorba a distribúcia katalógu v cestovnej kancelárii A}

Cestovná kancelária A vytvára ročne dva katalógy určené na letnú sezónu, ktorých obsah je prispôsobený ciel’ovej skupine zákazníkov (bežní, náročnejší zákazníci). Pri tvorbe katalógov uplatňuje efektívnu del'bu práce. Čast' činností zabezpečuje dodávatel'sky, pre outsourcing si pritom stanoví finančný limit. Proces tvorby katalógu trvá približne dva mesiace.

O obsahu katalógov rozhoduje produktový manažér. Ciel'ové miesta, ktoré budú tvorit' ponuku katalógu vyberá na základe záujmu zákazníkov. Výber ubytovacích zariadení závisí od ich lokalizácie, referencií zákazníkov a subjektívnych dojmov produktového manažéra, ktorý ich osobne navštívil. V d'alšej fáze produktový manažér načrtne na papier štruktúru katalógu (poradie ponúkaných ciel’ových miest a ubytovacích zariadení). Texty do katalógu pripravuje spoločne celý tím zamestnancov, fotografie poskytujú jednotliví dodávatelia služieb. Cenníky vytvára ekonomické oddelenie, štruktúru, formu a dizajn tvorí marketingový manažér v spolupráci s grafickým štúdiom (uplatnenie outsourcingu).

Dodávatel’a, ktorý sa postará o dizajn katalógu si cestovná kancelária vyberá v závislosti od referencií a ceny. Dá si pritom vypracovat' viacero cenových ponúk. Vybranému grafickému štúdiu potom pošle podklady katalógu - fotografie vo formáte na uchovávanie statických obrázkov, texty v textovom procesore a cenníky v tabul'kovom procesore. Grafické štúdio postupne tvorí jednotlivé časti katalógu, ktoré operatívne posiela do cestovnej kancelárie na kontrolu. Cestovná kancelária skontroluje návrhy a zašle ich spät’ spolu s korektúrami. Tento postup sa pritom opakuje niekol'kokrát, kým sa nevytvorí finálna verzia katalógu.

Pred tlačou katalógu si cestovná kancelária na základe pomeru ceny a kvality vyberá druh papiera a stanovuje náklad. Potrebný počet kusov katalógov odhaduje podl'a skúseností z minulých období, súčasného počtu províznych predajcov, ako aj plánovaných účastí na vel'trhoch a výstavách cestovného ruchu. Katalóg si cestovná kancelária necháva tlačit' vo vybranej tlačiarni, čím ušetrí na odmene, ktorú by si za sprostredkovanie tlače naúčtovalo grafické štúdio.

Vytlačené katalógy cestovná kancelária vzápätí distribuuje províznym predajcom a zákazníkom, ktorí si v minulosti zakúpili jej produkty. Distribúcia katalógov sa uskutočnuuje aj na výstavách a vel'trhoch cestovného ruchu, ktorých sa cestovná kancelária zúčastňuje. Najväčší podiel katalógov sa distribuuje individuálnym záujemcom prostredníctvom prevádzkarne. V snahe zvýšit' dostupnost' katalógu ho cestovná kancelária uverejňuje aj na svojej internetovej stránke (v programe Flash Player).

\subsection{Tvorba a distribúcia katalógu v cestovnej kancelárii $B$}

Cestovná kancelária B vytvára ročne jeden katalóg s ponukou dovolenky pri mori. Ked’že má svojich stálych dodávatel'ov služieb, s ktorými je spokojná, obsah katalógu mení len minimálne. Proces tvorby katalógu je podobný ako v cestovnej kancelárií A. Trvá jeden mesiac.

Spracovanie návrhu katalógu majú na starosti referenti cestovnej kancelárie, ktorí ho predložia grafickému štúdiu v mieste sídla cestovnej kancelárie. Po odsúhlasení finálnej verzie sa katalóg tlačí rovnako v mieste pôsobenia cestovnej kancelárie. 
Počet vydaných katalógov sa pohybuje v rozsahu 6 až 10 tisíc kusov. Vel'ká čast' z nich sa zasiela províznym predajcom, zvyšok ostáva v prevádzkarni, kde si ich môžu vyzdvihnút' potenciáli zákazníci.

\subsection{Tvorba a distribúcia katalógu v cestovnej kancelárii $\mathbf{C}$}

Cestovná kancelária $\mathrm{C}$ tvorí ročne jeden katalóg, ktorý obsahuje ponuku pobytových aj poznávacích zájazdov. Okrem vlastnej ponuky prezentuje aj produkty dvoch partnerských cestovných kancelárií. S tvorbou katalógu začína po skončení letnej sezóny (v októbri), proces tvorby trvá jeden až dva mesiace.

Za tvorbu katalógu je zodpovedný tím manažérov v centrále cestovnej kancelárie. O ponuke katalógu rozhoduje riaditel'. Opisy jednotlivých zariadení a fotografie zabezpečujú dodávatelia služieb, prípadne zamestnanci cestovnej kancelárie počas služobnej cesty. Texty a fotografie sa v porovnaní s minulým obdobím menia vtedy, ak sa ubytovacie zariadenia rekonštruovali. Finálna verzia katalógu sa pripravuje v programe Servác. Spracúvajú ju referentky jednej z prevádzok. Pripravený katalóg sa posiela na tlač do reklamnej agentúry. Ako posledný sa koncipuje a tlačí obal katalógu, pretože sa naň vždy dodatočne tvorí „upútavka““ (napr. ,zl’ava na skorý nákup až do $20 \%$ \%).

Po vytlačení sa katalóg distribuuje do jednotlivých prevádzok cestovnej kancelárie (na jednu prevádzku pripadá približne 800 kusov) a províznym predajcom.

\subsection{Tvorba a distribúcia katalógu v cestovnej kancelárii $D$}

Cestovná kancelária D tvorí ročne jeden katalóg s ponukou letnej dovolenky. Zodpovednost' za jeho tvorbu nesie riaditel'ka (majitel'ka cestovnej kancelárie). Zvyčajne predstaví predbežný návrh katalógu svojim zamestnancom a následne im rozdelí úlohy a určí časový harmonogram ich plnenia. Proces tvorby katalógu trvá približne dva mesiace.

Text a fotografie do nového katalógu vyberajú zamestnanci z materiálov použitých pri tvorbe predchádzajúcich katalógov, z materiálov, ktoré sa získali pri kontrahovaní kapacít priamo $\mathrm{v}$ ciel'ových miestach, prípadne $\mathrm{z}$ iných zdrojov. Texty opisujúce ciel'ové miesta sa čerpajú z domácich i zahraničných turistických sprievodcov a doplńajú z internetových zdrojov. Texty o ubytovacích zariadeniach sa čerpajú z webových stránok poskytovatel'ov služieb a dopĺn̆ajú sa o osobné skúsenosti a dojmy riaditel’ky cestovnej kancelárie.

Formát a grafika katalógu sa nemení (snaha o to, aby bol pre zákazníkov aj sprostredkovatel'ov identifikovatel'ný). Grafickú úpravu pritom realizuje grafické štúdio. Pred vydaním sa katalóg posiela spät do cestovnej kancelárie na schválenie (kontrola obsahu a jazykovej stránky). Tlačí sa vo vybranej tlačiarni. Náklad sa determinuje na základe skúseností z predchádzajúcich sezón a z plánovaného počtu predaných zájazdov na nasledujúcu sezónu. Cestovná kancelária vychádza z predpokladu, že na získanie jedného zákazníka potrebuje pät' katalógov. Do úvahy sa však berie aj skutočnost', že čoraz viac zákazníkov získava informácie na internete (prehl'adnost', porovnatel'nost'). Cenníky sa tlačia neskôr na menej kvalitnom papieri (úspora finančných prostriedkov, finalizácia cien) a dodatočne sa vkladajú do katalógov. 
Katalóg sa po vytlačení distribuuje sprostredkovatel'om. Vel'ká čast' z celkového nákladu ostáva v prevádzkarni cestovnej kancelárie, kde si katalóg môžu vyzdvihnút’ potenciálni zákazníci.

\subsection{Tvorba a distribúcia katalógu v cestovnej kancelárii $\mathbf{E}$}

Za tvorbu katalógov v cestovnej kancelárii E je zodpovedná realizačná riaditel'ka. Návrh katalógov tvoria referenti vybraných prevádzkarní cestovnej kancelárie a schval'uje ho manažér danej prevádzkarne. Ročne sa v cestovnej kancelárií pripravujú tri katalógy - katalóg na letnú sezónu (ponuka pobytov pri mori), katalóg na zimnú sezónu (ponuka lyžovačiek), katalóg s ponukou pre školské kolektívy (školské pobyty). Grafická úprava a tlač katalógov sa zabezpečujú formou outsourcingu. Cestovná kancelária pritom spolupracuje s viacerými grafickými štúdiami a tlačiarňami. Vyberá ich podl’a sídla prevádzkarne, ktorá daný katalóg pripravuje. Proces tvorby katalógov trvá jeden až dva mesiace.

Obsah katalógov sa každoročne mení, v závislosti od ponuky konkurencie, požiadaviek zákazníkov a cenových podmienok dodávatel'ov služieb. Opisy zariadení a fotografie zabezpečujú dodávatelia služieb (posielajú ich elektronickou poštou alebo ich dodávajú na CD/DVD -romoch), prípadne zamestnanci cestovnej kancelárie počas služobných ciest. Sú upravované tak, aby čo najviac zodpovedali skutočnosti. Dodatočné informácie o primárnej a sekundárnej ponuke jednotlivých ciel’ových miest vyhl'adávajú referenti cestovnej kancelárie na internete.

Počet vydaných katalógov na letnú sezónu sa pohybuje od 25 do 30 tisíc kusov (do jednotlivých prevádzkarní sa pritom posiela približne 1500 kusov). Rozsah špecializovaných katalógov je výrazne menší - v závislosti od druhu katalógu ide o 500 až 2000 kusov.

Po vytlačení katalógov sa tieto rozposielajú do jednotlivých prevádzkarní (8), províznym predajcom (400), ako aj stálym zákazníkom a zákazníkom, ktorí si ho objednali prostredníctvom webovej stránky.

\section{Záver}

Tvorba a tlač katalógu je pre cestovnú kanceláriu náročným procesom, tak z organizačného, ako i finančného hl'adiska. Je úzko spojená s organizačno-technickou a ekonomickou stránkou tvorby produktu cestovnej kancelárie.

Každá zo skúmaných cestovných kancelárií pristupuje k tvorbe katalógu intuitívne na základe predchádzajúcich skúsenosti. Fázy tvorby katalógu nie sú pritom v zhode s fázami vytýčenými v teórii (Middleton, 1995). Rozhodnutie o distribúcii (podl’a teórie ide o štvrtú fázu v procese tvorby) zvyčajne predchádza zvyšným fázam, avšak konkrétne určenie nákladu a výber kvality papiera (súčast' determinovania vysielaného imidžu - podl'a teórie druhá fáza) si cestovné kancelárie nechávajú na poslednú chvíl'u. Kým formát katalógu cestovné kancelárie nemenia, jeho rozsah závisí od ponuky zájazdov. O obale sa cestovné kancelárie v súlade s teóriou rozhodujú tesne pred tlačou.

Informácie a obrázky, ktoré budú súčast'ou katalógu sa zhromažd'ujú už počas výberu dodávatel'ov služieb. Na začiatku procesu tvorby katalógu sa selektujú a dopíňajú z iných zdrojov. Niektoré cestovné kancelárie získavajú fotografie jednotlivých ciel'ových miest a zariadení počas služobnej cesty, iné priamo od ubytovacích zariadení, prípadne využívajú 
internetové zdroje (riziko porušovania autorských práv). Ked’že cenníky sa viažu na tvorbu cien jednotlivých produktov, určenie provízií, zliav, ap., pripravujú sa na poslednú chvíl'u a niekedy sa, tak ako sa uvádza v teórii, tlačia samostatne (tvoria samostatnú čast' katalógu). Cestovné kancelárie kladú vel'ký dôraz na výber obalu (upútanie pozornosti), rozhodujúca je však aj štruktúra katalógu (logickost', prehl'adnost') a jednoduchá použitel'nost' pre zákazníkov. Pri výbere papiera zvažujú kvalitu a cenu (primárne nemajú na pamäti ciel'ovú skupinu, pre ktorú sú produkty v katalógu určené ako sa to spomína v teórii). Grafickú realizáciu zväčša nechávajú na špecializovaný podnik (dôležitá je geografická blízkost' podniku). Náklad nestanovujú v počiatočnej fáze tvorby katalógu, ale často až tesne pred tlačou. Z obáv pred nutnost'ou dodatočnej tlače katalógov sa rozhodnú radšej pre tlač väčšieho počtu katalógov. Napriek tomu, že čoraz viac zákazníkov uprednostňuje elektronickú ponuku zájazdov, je tlačený katalóg neodmyslitel'nou súčast’ou klasickej cestovnej kancelárie. Pozornost' sa má preto sústredit' na tvorbu katalógu ul'ahčujúcemu rozhodnutie zákazníkov, ako aj na sledovanie jeho efektívnej distribúcie. Osobitnou otázkou je súlad obsahu katalógu s platnou legislatívou.

Vytvorený katalóg cestovnej kancelárie predstavuje kompromis medzi požiadavkami dopytu na autentické obšírne informácie oluxusnom statku cestovného ruchu a snahou podnikatel'ského subjektu predat' produkt (dôraz na pozitívne vlastnosti produktu verzus nevyhnutnost' rešpektovat' legislatívu) pri súčasnej snahe minimalizovat' náklady (nižší rozsah katalógu, vyššia efektívnost' distribúcie, odkaz na webovú stránku s podrobnejšími informáciami).

\section{Literatúra:}

[1] ATTL, P. 2002. Katalog jako základní komunikační nástroj cestovní kanceláře se zákazníkem. In Starostlivost' o zákazníka v cestovnom ruchu. Zborník z konferencie. Banská Bystrica : Ekonomická fakulta Univerzity Mateja Bela, 2002, s. 44 - 50.

[2] GÚČIK, M. 2004. Trh touroperátorov. In Gúčik, M., Šípková, I. Globalizácia a integrácia v cestovnom ruchu. Banská Bystrica : Slovak-Swiss Tourism, 2004. ISBN 80-969261-0-1, s. $99-119$.

[3] HOLlOWAY, J. Ch. 2004. Marketing for tourism. $4^{\text {th }}$ edition. Harlow : Pearson Education Limited, 2004. ISBN 0-273-68229-6.

[4] HORNER, S. SWARBROKE, J. 2004. International cases in tourism management. Oxford : Elsevier, 2004. ISBN 0-7506-5514-3.

[5] KUMAR, J. L. 2005. Encyclopedia of tourism in $21^{\text {st }}$ century. New Delhi : Anmol Publications, 2005. ISBN 81-261-2404-0.

[6] MidDleton, A.V. T. C., FYAlL, A., MORGAN, M., RANCHHOD, A. 2009. Marketing in travel and tourism. $4^{\text {th }}$ edition. Oxford : Butterworth-Heinemann, 2009. ISBN 978-0-7506-8693-8.

[7] MIDDLETON, V. T. C. 1995. Marketing in travel and tourism. $2^{\text {th }}$ edition. Oxford : Elsevier, 1995. ISBN 0-75060-973-7.

[8] ORIEŠKA, J. 2010. Služby v cestovním ruchu. Praha : Idea servis, 2010. ISBN 978-8085970-68-5.

[9] PAGE, S. 2009. Tourism management. Managing for change. 3 th edition. Oxford : Butterworth-Heinemann, 2009. ISBN 978-1-85617-602-6.

[10] Zákon 281/2001 Z. z. o zájazdoch, podmienkach podnikania cestovných kancelárií a cestovných agentúr a o zmene a doplnení Občianskeho zákonníka v znení neskorších predpisov. 
JEL L83

Ing. Kristína Pompurová, PhD.

odborná asistentka Katedry cestovného ruchu a spoločného stravovania Ekonomická fakulta

Univerzita Mateja Bela

Tajovského 10, 97590 Banská Bystrica

Slovenská republika

kristina.pompurova@umb.sk 